\begin{tabular}{|c|c|c|c|c|c|c|}
\hline \multirow{4}{*}{ Impact Factor: } & ISRA (India) & $=3.117$ & SIS (USA) & $=0.912$ & ICV (Poland) & $=6.630$ \\
\hline & ISI (Dubai, UAI & $=0.829$ & РИНЦ (Russia) & $=0.156$ & PIF (India) & $=1.940$ \\
\hline & GIF (Australia) & $=0.564$ & ESJI (KZ) & $=8.716$ & IBI (India) & $=4.260$ \\
\hline & JIF & $=1.500$ & SJIF (Morocco) & $=5.667$ & OAJI (USA) & $=0.350$ \\
\hline
\end{tabular}

\section{SOI: 1.1/TAS DOI: 10.15863/TAS International Scientific Journal Theoretical \& Applied Science}

p-ISSN: 2308-4944 (print) e-ISSN: 2409-0085 (online)

Year: 2019 Issue: $05 \quad$ Volume: 73

Published: $22.05 .2019 \quad \underline{\text { http://T-Science.org }}$
QR - Issue

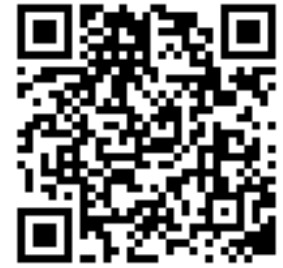

QR - Article

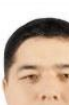

Sherali Abduvalievich Dusmanov

Samarkand state university

\title{
THEORETICAL AND PRACTICAL ISSUES OF FORMATION AND DEVELOPMENT OF ENTREPRENEURIAL PHILOSOPHY IN UZBEKISTAN
}

Abstract: This scientific article provides an overview of entrepreneurship as a socio-economic phenomenon and provides a set of social, economic, political, legal, ethical and moral factors affecting the formation and development of entrepreneurial philosophy, as well as a number of recommendations aimed at developing youth entrepreneurial thinking.

Key words: business, innovation, business philosophy, business culture, private entrepreneurship, clandestine business.

Language: English

Citation: Dusmanov, S. A. (2019). Theoretical and practical issues of formation and development of entrepreneurial philosophy in Uzbekistan. ISJ Theoretical \& Applied Science, 05 (73), 156-158.

Soi: http://s-o-i.org/1.1/TAS-05-73-28 Doi: crostef https://dx.doi.org/10.15863/TAS.2019.05.73.28

\section{Introduction}

In the 21 st century, labour able people from $40 \%$ to $55 \%$ of the economically developed countries of the world are working in the private sector of various small enterprises, firms and businesses, with a minimum of 20 personnel. The share of the total gross domestic product is $62 \%$ in France, $60 \%$ in Italy, 55\% in Japan, $54 \%$ in Germany, $53 \%$ in the UK, $52 \%$ in the United States, and $56 \%$ in general [1]. That is why small businesses and private entrepreneurship are becoming a major economic, political, and spiritual power worldwide.

Consequently, entrepreneurship exists as a social entity and its philosophical study of its formation and development laws is essential as an urgent problem.

The problem of positively solving a number of problems such as the prolongation of the global economic crisis, aggravation of competition, increasing unemployment, deteriorating environmental degradation, increasing population migration, the overthrow of material resources, and the rise of hunger and poverty, which is largely dependent on the laws, methods and means of small business and private entrepreneurship.

The share of employment in the economy is 78.0 in Japan, 71.0 in Italy, 69.5 in Germany, 56.0 in the United Kingdom, and 54 in the United States [2] due to the wide and broader access to small businesses and private entrepreneurship in developed countries, can be seen as positively solved by the above mentioned problems.

In Uzbekistan it is formed as $78.2 \%$ of those employed in the small business and private entrepreneurship, $\quad 61.9 \%$ in individual entrepreneurship and $16.3 \%$ in small businesses and microfirms make up $56.9 \%$ of the total.

The small business entities operating in Uzbekistan are 218,170, including 61220 in trade, 42,862 in industry, 21,796 in construction, 1,851 in agriculture, forestry and fishery. Overall, more than 10 million people in the country are engaged in small businesses and private entrepreneurship [3].

However, this is not enough. Unfounded investigations, corruption cases, low legal literacy, inadequate entrepreneurial skills and culture, and the incompleteness of bureaucratic barriers prevent to its development.

The head of state Sh.M.Mirziyoev said: "The World Bank ranked 134th our country's construction industry rating. This indicates that there are many problems in this area"[4], therefore," ...preventing entrepreneurship is assessed as a barrier to state policy and the policy of the President "[5]. Thus, the creation of a new philosophy of entrepreneurship in the minds 


\begin{tabular}{|c|c|c|c|c|c|c|}
\hline \multirow{4}{*}{ Impact Factor: } & ISRA (India) & $=3.117$ & SIS (USA) & $=0.912$ & ICV (Poland) & $=6.630$ \\
\hline & ISI (Dubai, UAI & $=0.829$ & РИНЦ (Russia & $=0.156$ & PIF (India) & $=1.940$ \\
\hline & GIF (Australia) & $=0.564$ & ESJI (KZ) & $=8.716$ & IBI (India) & $=4.260$ \\
\hline & JIF & $=1.500$ & SJIF (Morocco & $=5.667$ & OAJI (USA) & $=0.350$ \\
\hline
\end{tabular}

of young people by studying the historical roots, business ethics, and secular principles of entrepreneurship is one of the most urgent tasks of present time.

When we get into account that $64 \%$ of the population of the country is young, the majority of young people (the average age of population in Uzbekistan is 26.9) years are engaged.in the sphere of small business and private entrepreneurship. The objective of it is to create entrepreneurial skills of young entrepreneurs who have just started their business and become one of the priority directions of the youth policy currently underway in our country.

\section{Main part}

Entrepreneurship is a business that is earnings and making profits by producing and servicing goods based on the use of their property or others' property. Businesspersons are called entrepreneurs. Today, entrepreneurs are formed by workers, peasants, workers, and serve to the emergence and development of the middle class ownership. Among these, the number of young people is growing.

Young entrepreneurial skills are individual mental and physical attributes that reflect subjective circumstances of earning and making a profit by producing and servicing goods based on the use of their property or others' property. They can be sorted into skillful or incompetent in entrepreneurship.

We attach such qualities as wish, interest, talent, skill and power to the psychological and physical features inherent to the talented entrepreneur.

Accordingly, we consider as young entrepreneur who talented, skillful, constantly thinking and capable person who is interested in doing business. When we say that a incompetent young entrepreneur, we understand a person who is just interested in entrepreneurship, who is unlucky, untalented, indifferent, unable to do anything.

Nowadays, the problem of innovative development and development of youth entrepreneurship is of great importance.

"Active entrepreneurial business is an innovation that is based on modern approaches, advanced technology and management methods" [6].

The goal of innovative development of youth entrepreneurship is to create entrepreneurial philosophy that serves as a methodological basis for reflecting the laws and categories of their further development and determining the strategic directions for further development.

The ontological foundations of formation and development of entrepreneurial philosophy in Uzbekistan are all the material and spiritual wealth of the entrepreneurs, and the subjects gnoseological bases are engaged in entrepreneurial activity.

The first (empiric) bases for the formation and development of business philosophy are: 1) to educate a child from the beginning of the child's element of entrepreneurship, i.e. teaching children to do something by their own hands;

2) providing a wide range of opportunities for children to attend children at different clubs, especially in scientific and practical circles; 3 ) to teach the secrets of craftsmanship inherited from their ancestors in the mahallas and to train them to innovate modernization 4) to familiarize the mass media with news, especially in the magazines and scientificallypractical magazines, in practice organizing vision; 5) Continuously maintains the traditions of the "teacher and pupil" and etc.

Socio-economic factors affecting the formation and development of entrepreneurial philosophy in Uzbekistan include:

- own property;

- Availability of a private enterprise;

- Availability of funds in the bank;

- Availability of service charge;

- Availability of access to the consumer market;

- Competitiveness of the product;

- Availability of raw material resources and others.

A young businessman who wants to engage in entrepreneurial activity can achieve great success only when he or she adheres to these standards. However, if it does not take into account these factors, it will be economically degraded.

Political and legal factors influencing the formation and development of business philosophy are as follows:

- Presence of required normative and legal documents on entrepreneurship;

- level of legal literacy of the population;

- concluded contracts and their execution;

- legally distributed benefits;

- Relations with foreign entrepreneurs;

- Attitude towards various political institutions that are not legally valid;

- The ability of young people to adhere to the principles of political literacy and democratic thinking;

- the attitude to smuggled earnings.

Ethical and moral factors influencing the formation and development of business philosophy include: belief;

- the rise of the national idea to the level of

- harmony of national and universal values;

- Familiarity with advanced social and philosophical ideas about entrepreneurship;

- degree of compliance with universal ethical standards;

- Superiority of conscience;

- Rising bread to the level of ethical law;

- The extent to which ethical media can be addressed.

The ultimate goal of the formation and development of entrepreneurial philosophy in 


\begin{tabular}{|c|c|c|c|c|c|c|}
\hline \multirow{4}{*}{ Impact Factor: } & ISRA (India) & $=3.117$ & SIS (USA) & $=0.912$ & ICV (Poland) & $=6.630$ \\
\hline & ISI (Dubai, UAE & $=0.829$ & РИНЦ (Russia & $=0.156$ & PIF (India) & $=1.940$ \\
\hline & GIF (Australia) & $=0.564$ & ESJI (KZ) & $=8.716$ & IBI (India) & $=4.260$ \\
\hline & JIF & $=1.500$ & SJIF (Morocce & $=5.667$ & OAJI (USA) & $=0.350$ \\
\hline
\end{tabular}

Uzbekistan is to develop entrepreneurial thinking, based on a healthy outlook of people.

Entrepreneurial mindset is a theoretical basis for making profit and earning from their own property or other property, based on risk and entrepreneurship in accordance with socio-economic, political, legal, ethical and social norms of citizens and a system of ideas and ideas aimed at implementing practical actions. From this perspective, it is desirable to carry out the following activities for the formation and development of youth entrepreneurial thinking.

\section{Conclusion}

1. It is desirable for all educational establishments to organize their debates on the topic "Formation and development of entrepreneurial thinking in Uzbekistan: theory and practice" and based on new aspects of entrepreneurship, to formulate their entrepreneurial thinking skills.

2. Development of a project "Code of Ethics of Spiritual Culture of Young Entrepreneurs of Uzbekistan" under the auspices of officials and their submission to the public discussion and subsequent acceptance.

3. Publish a collection of words about entrepreneurship by world intellectuals and publish a collection titled "World Intellectual Property Entrepreneurship".

4. Development of the conceptual model of creating a "Young Uzbek entrepreneur's philosophical image".

\section{References:}

1. (n.d.). Development of small business and private entrepreneurship in the Republic of Uzbekistan. Retrieved 2019, from https://uz/uz/statinfo/kichik-biznes-vatadbirkorlik/tahliylar-kichik-biznes/432analiticheskie-materialy-uz/2031-o

2. (n.d). development of private entrepreneurship. Retrieved 2019, from https://stat.uz/eng/statinfo/kichik-biznes-vatadbirkorlik/tahliylar-kichik-biznes/432analiticheskie-materialy-uz/2031-o-zbekistonkichik-biznes-va-

3. Mirziyoev, S. M. (2019). Decree of the President of the Republic of Uzbekistan Shavkat Mirziyoev to Oliy Majlis. December 28, 2018. (p.19). Tashkent: "Uzbekistan", NMIU.

4. Mirziyoev, S. M. (2017). We build a free and prosperous democratic society together. // we continue our national development path with determination and bring it to a new level. (pp.147-148). Tashkent: "Uzbekistan" NMIU.

5. Mirziyoev, S. M. (2018). Reference to the President of the Republic of Uzbekistan Shavkat Mirziyoev to the Oliy Majlis. December 22, 2017. (p.19). Tashkent: Uzbekistan, NMIU.

6. Karimov, I. A. (1997). Uzbekistan at the turn of the twenty-first century: security threats, stability and guarantees of development. (p.325). Tashkent: Uzbekistan.
7. (2015). To get new achievements and bring our reforms to a new level - our most urgent task today. Rule 23. (p.404). Tashkent: Uzbekistan.

8. Ganiev, B. (2013). The philosophy of economics. The program of XXIII World Congress of Philosophy, Greece, Athens, 04-10 August 2013. p. 180

9. Temur, A. (2016). Tuzuklar. (p.544). Tashkent: Extremum press.

10. Forobiy, Abu Nasr (2016). City of Wise people. (p.186). Tashkent: Folk Heritage of A.Kadyri.

11. Locks, D. (2014). Two tractates about ruling. (p.484). Series: Biblioteka GVL - Chelyabinsk. Sotsium.

12. Laine, L. J. (2018). "Process philosophy of entrepreneurship and spiritual innovation". Aalto University School of Business, Helsinki.

13. (2018). Improvement of legal regulation of business activity in free economic zones in Uzbekistan. Doctor of Philosophical Sciences $(\mathrm{PhD})$ abstract of diss. (p.51). Tashkent.

14. Semenov, V. P. (2003). Upgrading innovationinvestment process and entrepreneurship: theory and methodology. (p.184). SPb.: SPBGIEU.

15. Shcherbatikh, Y. V. (2009). Psychology of entrepreneurship and business. (p.97). SP: Peter. 